\begin{tabular}{|c|c|c|c|c|c|c|}
\hline \multirow{4}{*}{ Impact Factor: } & ISRA (India) & $=3.117$ & SIS (USA) & $=0.912$ & ICV (Poland) & $=6.630$ \\
\hline & ISI (Dubai, UAE & $=0.829$ & РИНЦ (Russia & $=0.156$ & PIF (India) & $=1.940$ \\
\hline & GIF (Australia) & $=0.564$ & ESJI (KZ) & $=8.716$ & IBI (India) & $=4.260$ \\
\hline & JIF & $=1.500$ & SJIF (Morocco & $=5.667$ & OAJI (USA) & $=0.350$ \\
\hline
\end{tabular}

SOI: $1.1 /$ TAS $\quad$ DOI: $10.15863 / T A S$
International Scientific Journal
Theoretical \& Applied Science
p-ISSN: $2308-4944$ (print) $\quad$ e-ISSN: $2409-0085$ (online)
Year: $2019 \quad$ Issue: $03 \quad$ volume: 71
Published: $30.03 .2019 \quad \underline{\text { http://T-Science.org }}$

SECTION 31. Economic research, finance, innovation, risk management.
QR - Issue
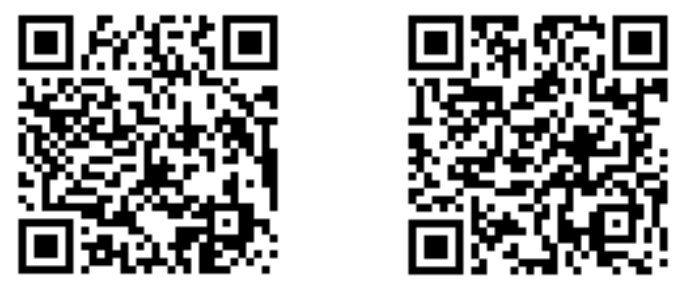

Saidvali Shukrullaevich Yusupov

Ph.D, docent,

Customs Institute of the State Customs Committee of the Republic of Uzbekistan

\title{
STRATEGIC OF DEVELOPMENT OF EXPORT POTENTIAL FOR ENGINEERING INDUSTRY OF UZBEKISTAN
}

Abstract: The article discusses the development of the textile industry of the Republic of Uzbekistan, as well as its role in ensuring economic growth. The export potential of the country's textile industry has been analyzed, and directions for increasing the country's export potential have been proposed.

Key words: light industry, investment, export, export potential, textiles, cotton fiber, yarn.

Language: English

Citation: Yusupov, S. S. (2019). Strategic of development of export potential for engineering industry of Uzbekistan. ISJ Theoretical \& Applied Science, 03 (71), 584-588.

Soi: http://s-o-i.org/1.1/TAS-03-71-59 Doi: crossef https://dx.doi.org/10.15863/TAS.2019.03.71.59

\section{Introduction}

Given the growing demand for natural fibers in the world market today, it should be noted that Uzbekistan has wide opportunities to be recognized not only as raw cotton, but also as an exporter of finished textile and light industry products.

Due to the production of consumer goods in the textile industry, it stands at the central place in the production of industrial products, which, in turn, is a major part of the market. In addition, the network provides a large number of jobs for the country, including the employment of women in the industry, which helps maintain the demographic balance in the industrial regions. One of the most important issues is the growth of export potential.

One of the major problems facing the light industry today is the fact that the product is exported rather than ready, but in semi-ready mode. As noted by President Islam Karimov, "Currently $40 \%$ of cotton fiber grown in our country is processed and the rest is naturally exported. The calculations show that if we export yarn, not raw materials, we export more than 1.4 times more fiber than fiber. If we sell cotton as a finished product, the volume of exports will increase by 6 times ".

\section{Literature review}

Researches in field of development and modernisation of economy were investigated by scientists as well as: Astapenko N.V., Akhunova G., Akhmadeev M., Abdurakhmanov K.Kh., Asaul A.N.,
Allaeva G.Zh., Boev A.N., Bodrikova OA, Zharikov AV, Shiryaeva Yu.S., Bakhur A. B., Bendikov M. A., Beregovoy V.A., Bekmurodov A.Sh., E. Balakireva, Babintsev B. C., Blinov V. M., Vagizov V.I., and others. [1-12]

\section{Analysis and results}

As of 01.01.2018, Uztashafilishanoat Association has 410 enterprises, 5 joint-stock companies, 66 joint ventures, 72 foreign companies, 235 limited liability companies and 22 other organizational-legal entities and organizations. is increasing. It should be noted that the products manufactured by joint ventures make up about $30 \%$ of the industrial production and $88.1 \%$ of their products are exported. Nowadays, light industry accounts for $1 / 3$ of the total labor force, while the share of light industry products is $13.4 \%$ of total industrial output and $55 \%$ of consumer goods.

Light industry of the Republic is developing at high rates. If in $19917 \%$ of the cotton fiber produced in the country was processed, today light industry enterprises process $45 \%$ raw cotton. According to the Decree of the President of the Republic of Uzbekistan dated 21.12.2016, No. 2687, the processing of cotton fiber in 2019 will reach $76 \%$. 100\% of raw cotton grown in our country is defined by the principle of self-reprocessing, exporting of products by 2.5 times and production capacity by 3 times. [13]

At present, the capacity of cotton fiber processing enterprises in the field is more than 522 


\begin{tabular}{|c|c|c|c|c|c|c|}
\hline \multirow{4}{*}{ Impact Factor: } & ISRA (India) & $=3.117$ & SIS (USA) & $=0.912$ & ICV (Poland) & $=6.630$ \\
\hline & ISI (Dubai, UAE & $=0.829$ & РИНЦ (Russia & $=0.156$ & PIF (India) & $=1.940$ \\
\hline & GIF (Australia) & $=0.564$ & ESJI (KZ) & $=8.716$ & IBI (India) & $=4.260$ \\
\hline & JIF & $=1.500$ & SJIF (Morocco & $=5.667$ & OAJI (USA) & $=0.350$ \\
\hline
\end{tabular}

thousand tons of cotton, fabric and silk fabrics, with a capacity of 276.0 mill. 101,0 thousand tons of knitted fabrics, annual capacity of sewing and knitting products - 270,5 million tons. and the strength of stock and hosiery - 45.0 mill. the pair.

The textile and light industry of the Republic is developing at high rates (Table 1).

Table 1. Dynamics of production volumes in 2014-2017 by "Uztakkimilshank" association

\begin{tabular}{|l|c|r|r|r|r|}
\hline \multicolumn{1}{|c|}{ Products } & Unit & $\mathbf{2 0 1 4 y .}$ & \multicolumn{1}{c|}{$\mathbf{2 0 1 5}$} & \multicolumn{1}{c|}{$\mathbf{2 0 1 6}$} & \multicolumn{1}{c|}{$\mathbf{2 0 1 7}$} \\
& & & y. & \multicolumn{1}{c|}{ y. } \\
\hline Cotton patchwork & & & & \\
\hline Ready-made cotton fabric & Mhous.ton & 257,8 & 307,2 & 348,6 & 385,2 \\
\hline Silk thread fiber & Ton & 154,9 & 182,9 & 198,7 & 238,4 \\
\hline Knitted fabric & Ton & 1016,4 & 1077,7 & 1230,1 & 1291,5 \\
\hline Knitwear items & Million pieces & 166,3 & 53400 & 62800 & 69900 \\
\hline Socks Products & Million pairs & 29200 & 38900 & 219,4 & 274,3 \\
\hline Sewing products at wholesale prices & Million sums & 28700 & 30800 & 37900 & 49300 \\
\hline Export & Million dollars & 865,1 & 1050,1 & 1170,0 & 1350,0 \\
\hline
\end{tabular}

Source: author's calculation.

Enterprises of the Uztoqishmashsanoat Association have the tendency to increase the volumes of raw cotton processing in 2014-2017. In 2014, 285 thousand tons of raw cotton was processed, in 2015 it was 260 thousand tons, in 2016 - 420 thousand tons, and in 2017 the volume of raw cotton processing reached 642 thousand tons, 2017 growth rates were $152,98 \%$.

At present, the textile industry plays an important strategic and reputational role in the economy of the Republic of Uzbekistan, and its interest in it is increasing day by day and at the same time, $20 \%$ of the industry's products are directly marketed with consumer goods, high employment and export potential This branch of the industry should play an important role in the growth of the economy and production potential of the republic. [14]

During the years of independence, the industry has invested 2.5 billion soums. more than $\$ 1$ billion of foreign investments were attracted and more than 200 companies with the participation of investors from Germany, Switzerland, South Korea, Turkey, Japan, Singapore, the USA and India were commissioned. In particular, investment projects for the production of more than 100 finished goods (upper and underwear, sportswear, clothes for adults and children, etc.) were implemented.

The main directions of the development strategy of textile and light industry in Uzbekistan:

- Re-equipment and modernization of operating enterprises;

- Creation of new high-tech enterprises;

- Expansion of deep processing of cotton fiber;

- consumer goods production;

- replenishment of the domestic market;

- treatment of export;

- creation of new jobs;

- training and retraining of personnel;

- restoration of textile machinery.

The industry has launched modern spinning machines, textile, silk fibers, paints, weaving, finishing and sewing equipment manufacturers of the world's leading machineries. Exports of goods of the enterprises of the community have exceeded $\$ 1$ billion (Table 2).

It is exported to more than 50 countries. He is a member of the International Textile Federation of Uzbekistan and has also signed cooperation agreements with textile associations in more than 30 countries.[15]

Table 2. Enterprises of "Uztokimachiliksanoat" Association export dynamics, mln. In US dollars

\begin{tabular}{|c|c|c|c|c|c|c|c|c|c|c|}
\hline Product Types & $\mathbf{2 0 0 8}$ & $\mathbf{2 0 0 9}$ & $\mathbf{2 0 1 0}$ & $\mathbf{2 0 1 1}$ & $\mathbf{2 0 1 2}$ & $\mathbf{2 0 1 3}$ & $\mathbf{2 0 1 4}$ & $\mathbf{2 0 1 5}$ & $\mathbf{2 0 1 6}$ & $\mathbf{2 0 1 7}$ \\
\hline Yarn of yarn & 202,1 & 249,2 & 318,5 & 475,7 & 561,3 & 617,4 & 673,0 & 733,5 & 799,6 & 871,5 \\
\hline Ribbon fabric & 35,9 & 55,8 & 56,7 & 65,2 & 83,5 & 103,5 & 112,8 & 123,0 & 134,0 & 146,1 \\
\hline Silk fabrics & 0 & 0,04 & 0,06 & 0,5 & 0,7 & 1,1 & 1,2 & 2,3 & 2,8 & 3,3 \\
\hline Raw silk & 10,8 & 11,4 & 12,1 & 12,8 & 13,5 & 14,0 & 13,0 & 15,8 & 13,1 & 11,2 \\
\hline Socks Products & 1,1 & 2,2 & 2,7 & 2,9 & 3,3 & 3,4 & 6,0 & 6,2 & 3,2 & 0,6 \\
\hline Knitted fabric & 8,0 & 34,2 & 40,4 & 50,6 & 63,2 & 79,0 & 86,1 & 93,9 & 102,3 & 111,5 \\
\hline
\end{tabular}

Source: author's calculation. 


\begin{tabular}{|c|c|c|c|c|c|c|}
\hline \multirow{4}{*}{ Impact Factor: } & ISRA (India) & $=3.117$ & SIS (USA) & $=0.912$ & ICV (Poland) & $=6.630$ \\
\hline & ISI (Dubai, UAE & $=0.829$ & РИНЦ (Russia) & $=0.156$ & PIF (India) & $=1.940$ \\
\hline & GIF (Australia) & $=0.564$ & ESJI (KZ) & $=8.716$ & IBI (India) & $=4.260$ \\
\hline & JIF & $=1.500$ & SJIF (Morocco) & $=5.667$ & OAJI (USA) & $=0.350$ \\
\hline
\end{tabular}

The volume of goods produced by the enterprises of the Uztishkimilanoat Association in 2017 will reach 3714.5 billion soums. The amount of annual exports amounted to 1170.0 mill. US dollars. Import-substituting raw materials, materials and consumer goods in 2016 increased by $118 \%$, or by 473.0 mill. Over USD. Exports of light industry products increased by 25 times in comparison with 1994. Export volumes accounted for $70.2 \%$ of the total output.

Since the 2000s, a new era has been launched in exports of textile, knitwear and silk products. It should be noted that in the light industry of Uzbekistan in the 1990s only cotton has been exported, Uzbekistan has wide opportunities to be recognized not only as raw cotton, but also as exporter of finished textile and light industry products.

As can be seen in Table 2, the volume of exports of textile products for 2014-2017 is $865.1 \mathrm{mln}$. 1350,0 mln. or by 1.6 times the export volume. In 2017 , the growth rates of exports amounted to $115.5 \%$.

If we analyze the structure of exports, we can see that the share of cotton yarn in the total textile industry decreased, and the share of cotton yarn and knitted garments increased (Table 3).

Table 3. The structure of the association "Uztokimachiliksanoat" in 2010-2017

\begin{tabular}{|c|r|r|r|r|r|}
\hline $\begin{array}{c}\text { Export of light } \\
\text { industry } \\
\text { products, } \%\end{array}$ & cotton yarn & $\begin{array}{c}\text { Knitted and } \\
\text { crocheted } \\
\text { appare }\end{array}$ & \multicolumn{1}{|c|}{ Yarn } & $\begin{array}{c}\text { Raw knitted } \\
\text { fabric }\end{array}$ & Silk thread \\
\hline 2010 й. & 58,0 & 25,0 & 7,0 & 5,2 & 2,8 \\
\hline 2014 й. & 44,2 & 33,8 & 16,6 & 4,4 & 1,0 \\
\hline 2017 й. & 38,5 & 35,2 & 19,6 & 5,5 & 1,2 \\
\hline
\end{tabular}

Source: author's calculation.

If the share of cotton yarn in 2010 was $58 \%$, in 2017 it would be $38.5 \%$, while the share of export of finished knitted and crocheted goods from $25 \%$ to $33.2 \%$, and cotton fiber exports - $7 \%$ from $19.6 \%$ to $19.6 \%$. However, despite the fact that Uzbekistan still holds the leading position in exports, exports of cotton fiber are still in place. However, it is well known now that the country can benefit from the export of textile products and, moreover, finished goods.
The following table shows that if the finished products are exported instead of 1 ton of cotton fiber in our republic, the rate of foreign exchange inflow to the republic will be more than $\$ 3,200$. At the same time, additional jobs will be created at enterprises established for the production of finished goods. This, in turn, will help to reduce unemployment among the population.

Table 4. Increase in added value of textile products

\begin{tabular}{|l|c|c|c|}
\hline Product type & Volume & Additional product & Price \\
\hline Cotton fiber & 1 кг & & $1,04 \$$ \\
\hline Knit & 0,88 кг & $1,4 \$$ & $2,44 \$$ \\
\hline Tissue & 0,77 кг & $0,2 \$$ & $2,64 \$$ \\
\hline Ready product & 3 дона & $1,6 \$$ & $4,24 \$$ \\
\hline
\end{tabular}

Source: author's calculation.

The development of the garment industry in this area plays an important role. This is due to the fact that the share of knitwear enterprises in various sectors of the light industry is $45.1 \%$. If, as of January 1, 2018, , 410 of which are enterprises of the Uztishmashafanoat Association, of which 138 are knitwear enterprises.

The company's geography of exports is expanding year by year. By 2016, the products produced by the company's products were exported to
58 countries, EU and CIS countries, as well as to China, South Korea, Turkey, India, UAE and other countries. In particular, exports to Turkey increased by $8.3 \%$, EU countries $-12.6 \%$, South Korea - $14.1 \%$, China - 5.4\%, CIS $-61.0 \%, 3.6 \% \%$ i was sent to others. The Association of textile products and marketing has been established within the Association of Textile Products, which examines the conjuncture of world textile industry products, analyzes the 


\begin{tabular}{|c|c|c|c|c|c|c|}
\hline \multirow{4}{*}{ Impact Factor: } & ISRA (India) & $=3.117$ & SIS (USA) & $=0.912$ & ICV (Poland) & $=6.630$ \\
\hline & ISI (Dubai, UAE & $=0.829$ & РИНЦ (Russia & $=0.156$ & PIF (India) & $=1.940$ \\
\hline & GIF (Australia) & $=0.564$ & ESJI (KZ) & $=8.716$ & IBI (India) & $=4.260$ \\
\hline & JIF & $=1.500$ & SJIF (Morocco & $=5.667$ & OAJI (USA) & $=0.350$ \\
\hline
\end{tabular}

situation on the demand, develops proposals for the implementation of the price policy by the enterprises, the direction of exports. It also helps our domestic producers to communicate with foreign consumers, to create mutually beneficial agreements.

The company pays great attention to the issues of import substituting products, and the structure of imports on its enterprises is thoroughly studied. In particular, in January-December of the year 2017, Imported products worth US \$ 99.4 million were imported. The share of equipment and spare parts of the US dollar accounted for $67 \%$ of the total volume of imported goods.

Table 5. Export geography of textile products in 2017

\begin{tabular}{|l|r|r|}
\hline Importing countries & Export volume. USD & Share, \% \\
\hline CIS & 823560 & 61,0 \\
\hline South Korea & 189013 & 14,1 \\
\hline European countries & 170112 & 12,6 \\
\hline Turkey & 112057 & 8,3 \\
\hline Chinese & 72905 & 5,4 \\
\hline Other countries & 48604 & 3,6 \\
\hline Total: & $\mathbf{1 3 5 0 1 0 0}$ & $\mathbf{1 0 0}$ \\
\hline
\end{tabular}

Source: author's calculation.

If we analyze the geography of textile products exported by enterprises of the Uztashakimilanoat Association in 2018, we can see that the products are mainly exported to Europe, Asia, Africa and North America. [13]

In Europe, except for Russia, Ukraine and Belarus, mainly yarn and cotton yarn have been exported to all countries. It should be noted that $100 \%$ stockings are exported to Russia. Most of the non- woven fabrics and knitted fabrics are exported to Russia, with $89-90 \%$. The Russian state takes the leading role in the export of the textile industry of our republic. [14]

Important role in the development of the textile and light industry of the Republic, as well as the modern machinery and equipment, as well as the furnishings and auxiliary materials, in the quality of manufactured products.

Table 6. Import of raw materials and materials required for production of textile products in the system of "UztakkimilSanoat", mln. in US dollars

\begin{tabular}{|l|r|r|r|r|}
\hline Type of imported goods & $\mathbf{2 0 1 4} \mathbf{y} \cdot$ & $\mathbf{2 0 1 5} \mathbf{y}$ & $\mathbf{2 0 1 6} \mathbf{~} \cdot$ & $\mathbf{2 0 1 7} \mathbf{y}$ \\
\hline Devices and parts & 55,1 & 96,4 & 107,3 & 122,1 \\
\hline Raw materials and auxiliary materials & 37,7 & 44,4 & 131 & 135,6 \\
\hline Total import volume & 92,8 & 106,2 & 238,3 & 253,7 \\
\hline
\end{tabular}

Source: author's calculation.

Table 7 shows that in 2014-2017 imports of equipment and accessories, as well as furnishing and auxiliary materials to the enterprises of Uztashakimilanoat Association. Imported machinery and equipment are imported in the structure of imports. It is worth mentioning that Riter, one of the world's leading machine-building firms, has been investing in the production of textile machinery manufactured by Rither in the Republic of Uzbekistan at Riter Machine Plant. [15]
The enterprises of the Uztakimachilik Industry Association are also working to meet the demand for quality materials and supplies, and a number of enterprises are being created to produce furnishings for the development of light industry. [16]

\section{Conclusions}

We can conclude that it is expedient to work in the development of the textile and light industry of the Republic of Uzbekistan, as well as to increase its export potential, to produce high quality finished 


\begin{tabular}{|c|c|c|c|c|c|c|}
\hline \multirow{4}{*}{ Impact Factor: } & ISRA (India) & $=3.117$ & SIS (USA) & $=0.912$ & ICV (Poland) & $=6.630$ \\
\hline & ISI (Dubai, UAE & $=0.829$ & РИНЦ (Russia & $=0.156$ & PIF (India) & $=1.940$ \\
\hline & GIF (Australia) & $=0.564$ & ESJI (KZ) & $=8.716$ & IBI (India) & $=4.260$ \\
\hline & JIF & $=1.500$ & SJIF (Morocco & $=5.667$ & OAJI (USA) & $=0.350$ \\
\hline
\end{tabular}

textile and light industry products and to increase their export potential with high added value.

In the near future it is proposed to implement the following tasks for the development of export potential of our country:

Sustainable industrialization;

- Increase in domestic investment aimed at financing of technical facilities modernization and renovation;

- Forming competitive corporations in domestic, foreign and domestic markets;
- Interdisciplinarity of economics;

- optimization of the banking system, optimization of the national currency exchange rate, and the lowering of inflation as low as possible;

- direct involvement of foreign investments, attraction of new advanced technologies and creation of joint ventures for expansion of export potential;

Creation of an organizational-legal basis for the formation of the export-oriented structure of the economy.

\section{References:}

1. Abryutin, M. S. (2004). Enterprise Economics: Training. Deloiservice. (pp.35-36)

2. Bendikov, M. A., \& Frolov, I. E. (2008). The role of the innovation potential in the modernization of the economy: domestic and foreign experience. Management in Russia and abroad, № 1, 36-38.

3. Doeringer Dickerson, C. G. (2004). Textiles and apparel in the global economy. 3rd ed. (pp.125127). NJ: M\$P-Hall.; Nordas H. K.

4. Gretchenko, A. A. (2009). The Foreign Experience in the Formation of Innovation Policy. Innovations and Investments, No. 3, 4551.

5. Forster, E., \& Ryants, B. (1983). Methods of correlation and regression analysis. A guide for economists. (p.304).

6. Forza, C., \& Salvador, F. (2001). Information flow for high-performance manufacturing. International Journal of Production Economics 70, Elsevier Press, 21-36.

7. Tursunov, B. O. (2017). Metody otsenki ekonomicheskoy nadezhnosti tekstil"nogo predpriyatiya $v$ usloviyakh rynochnoy ekonomiki. V sbornike: Teoriya i praktika organizatsii promyshlennogo proizvodstva. Effektivnost' organizatsii i upravleniya promyshlennymi predpriyatiyami: problemy i puti resheniya Materialy Mezhdunarodnoy nauchno-prakticheskoy konferentsii. (p.139144). Voronezhskiy gosudarstvennyy tekhnicheskiy universitet.

8. Tursunov, B. O. (2017). Perspektivy razvitiya tekstil"noy promyshlennosti v Uzbekistane. Menedzhment $v$ Rossii $i$ za rubezhom, № 4, 7884.

9. Tursunov, B. O. (2017). Strategiya razvitiya legkoy promyshlennosti respubliki Uzbekistan.
Vestnik Instituta ekonomiki Rossiyskoy akademii nauk, № 5, 146-155.

10. Tursunov, B. O. (2017). Teoreticheskie aspekty proizvodstvennoy moshchnosti tekstil"nykh predpriyatiy v sovremennykh usloviyakh. Nauchno-analiticheskiy zhurnal Nauka $i$ praktika Rossiyskogo ekonomicheskogo universiteta im. G.V. Plekhanova, № 4 (28), 5768.

11. Tursunov, B. O. (2017). Principles and functions of management of production capacity. Voprosy upravleniya, № 3 (46), 174-178.

12. Tursunov, B. O. (2017). Upravlenie proizvodstvennymi zapasami $\mathrm{v}$ tekstil"nykh predpriyatiyakh. Nauchnaya mysl', T. 1, № 3 (25), 117-125.

13. Tursunov, B. (2017). Features of the method of calculation of production capacities of the textile enterprises. Byulleten' nauki $i$ praktiki, № 10 (23), 213-222.

14. Tursunov, B. (2017). Ways of increasing the efficiency of usage the production capacity of textile enterprises. Byulleten' nauki i praktiki, № 8 (21), 232-242.

15. Tursunov, B. O. (2017). metody otsenki ekonomicheskoy nadezhnosti tekstil"nogo predpriyatiya $v$ usloviyakh rynochnoy ekonomiki. V sbornike: Teoriya i praktika organizatsii promyshlennogo proizvodstva. Effektivnost' organizatsii i upravleniya promyshlennymi predpriyatiyami: problemy $\mathrm{i}$ puti resheniya Materialy Mezhdunarodnoy nauchno-prakticheskoy konferentsii. (pp.139144). Voronezhskiy gosudarstvennyy tekhnicheskiy universitet.

16. Ubatdullaev, S. N. (2007). Economic institutes: creation and development. (p.152). Tashkent: Istiqlol. 